\title{
The Palliative Radiotherapy of Classic Kaposi's Sarcoma of Foot Region: Retrospective Evaluation
}

\author{
Muge AKMANSU' ${ }^{1}$, Fatih GOKSEL ${ }^{2}$, O. Petek ERPOLAT ${ }^{1}$, Diclehan UNSAL ${ }^{1}$, \\ Eray KARAHACIOGLU ${ }^{1}$, Huseyin BORA ${ }^{1}$ \\ ${ }^{1}$ Gazi University Faculty of Medicine, Department of Radiation Oncology, Ankara \\ ${ }^{2}$ Erzurum Regional Training and Research Hospital, Department of Radiation Oncology, Erzurum, TURKEY
}

\begin{abstract}
The life quality of the patients with classic Kaposi's sarcoma exit in the foot region (toes, dorsum pedis, plantar pedis and region calcaneus) were impaired due to the walking or the pain while wearing shoes. The widely used radiotherapy in this patient group is applied with different doses and fractionation schemes. The data is limited for evaluating response and toxicity of radiation to optimized radiotherapy techniques of foot' CKS. The aim of the study was to assess the effectiveness and safety of RT for these patients. Thirty-one therapy areas of 15 patients with histological confirmed Kaposi's sarcoma in the foot region and treated between 1999 and 2005 were evaluated retrospectively. The male/female ratio was 2.75/1 and the median age was 63 years of age. The most frequently used radiotherapy scheme was 3000cGy in 10 fractions.

The median follow-up time was 68.4 months. The complete response ratios were $86.7 \%, 93.3 \%, 93.3 \%$ for 30 therapy areas at 6, 12 months and 5 years, consecutively. Acute complications were observed in 17 (54.8\%) therapy areas. All side effects developed due to the therapy were controlled with supportive treatment. Normal foot movements were ensured within 2-4 weeks after the radiotherapy. According to our results, the radiotherapy is effective and safe therapy modality for Kaposi's sarcoma of the foot region. However, the first response to radiation is usually frustrating and it may increase the patients' complaint about the foot due to the acute toxicity. This can be improved completely with supportive therapy.
\end{abstract}

Keywords: Classic Kaposi's sarcoma, Radiotherapy, Foot region

\section{ÖZET}

\begin{abstract}
Ayak Bölgesinin Klasik Kaposi Sarkomunun Palyatif Radyoterapisi: Retrospektif Değerlendirme
Ayak bölgesinde (ayak parmakları, dorsum pedis, plantar pedis, regio calcanea) klasik Kaposi sarkomu bulunan hastaların yaşam kalitesi; yürürken veya ayakkabı giyerken çektikleri acı nedeniyle bozulmaktadır. Bu hasta grubunda sıklıkla kullanılan radyoterapi, farklı doz ve fraksiyon şemaları ile uygulanmaktadır. Ayağın klasik Kaposi sarkomunun radyoterapi tekniklerini optimize etmek için radyasyonun yanııını ve toksisitesini değerlendiren veri azdır. Çalışmanın amacı bu hastalar için radyoterapinin etkinliğini ve güvenilirliğini değerlendirmektir. 1999 ve 2005 yılları arasında tedavi olmuş ve ayak bölgesindeki Kaposi sarkomu histolojik olarak doğrulanmış 15 hastanın 31 tedavi bölgesi retrospektif olarak değerlendirilmiştir. Erkek/kadın oranı 2.75/1'dir, medyan yaş 63'tür. En sık kullanılan radyoterapi şeması 10 fraksiyonda 3000 cGy'dir. Medyan izlem süresi 68.4 aydır. Otuz tedavi alanı için 6 , 12 . aylardaki ve 5.yldaki tam yanıt oranı sırayla \%87, 93.3\%, 93.3\%'tür. Akut komplikasyonlar 17 (\%54.8) tedavi alanında gözlenmiştir. Tedaviye bağ॥ gelişen yan etkilerin tümü destek tedavi ile kontrol altına alınmıştır. Radyoterapi sonrası 2-4 hafta içinde normal ayak hareketleri sağlanmıştır. Radyoterapi ayak bölgesinin Kaposi sarkomu için etkili ve güvenli bir tedavi modalitesidir. Radyasyona ilk yanıt genellikle hayal kırıkığı yaratır ve ayaktaki şikayetler radyasyonun akut toksisitesine bağı artsa da, bu durum destek tedaviyle tamamen iyileşebilir.
\end{abstract}

Anahtar Kelimeler: Klasik Kaposi sarkom, Radyoterapi, Ayak bölgesi 


\section{INTRODUCTION}

Kaposi Sarcoma (KS) is a malignant vascular neoplasm first defined by Moritz Kaposi, an Austria-Hungarian dermatologist in 1872 as "Multiple Idiopathic Hemorrhagic Sarcoma".' Four clinical subtypes were reported such as Classic Kaposi Sarcoma (CKS), endemic or African KS, immunosuppression associated $\mathrm{KS}$, and AIDS associated KS. ${ }^{2}$ The CKS is frequently seen in elderly people, particularly men of Mediterranean heritage or Eastern Europe Jewish (Ashkenazi) and have usually benign, slow pattern. ${ }^{2,3}$ The lesions typically occur on the lower legs and feet in the form of macules and/or papules with progression to nodular or plaque form. However, the features of the lesions depend on the variation of disease progression. ${ }^{4}$ The progress of the disease occurs typically by the local extension developed as a result of a lateral growth. Sometimes rapid growth can lead to painful, hemorrhagic lesions. The central necrosis and ulceration or massive edema may accompany in further progression. ${ }^{3}$ Although manifestations of KS are site specific, when the disease involves the foot, the life quality of these patients is impaired due to pain, swelling and discomfort while wearing socks and shoes or walking.

The treatment of KS is mainly palliative. Multidisciplinary treatment methods with various response ratios are applied for the therapy of KS, such as radiotherapy (RT), intralesional interferon alfa- $2 b$ and systemic chemotherapy, cryotherapy, hormonotherapy, laser excision and infrared coagulation depending on clinical form and stage. ${ }^{5.8}$ Within these treatment modalities, RT is a useful method to improve the quality of life of the patients or treatment response ratio with minimum toxicity. However, RT is widely used in foot KS with different energies and different fraction schemes at different doses; the limited literature is available for response and toxicity to optimized RT techniques of foot' CKS. This study aimed to determine either clinical characteristics of patients with CKS in foot region or the efficacy and safety of radiotherapy.

\section{PATIENTS AND METHODS}

Fifteen patients with histological confirmed Kaposi's sarcoma in foot region (toes, dorsum pedis, plantar pedis and region calcaneus) treated in our department between the dates of 1999 and 2005, were evaluated

\begin{tabular}{|c|c|}
\hline No. of patients & 15 \\
\hline \multicolumn{2}{|l|}{ Age (years) } \\
\hline Median & 63 \\
\hline Range & $44-76$ \\
\hline \multicolumn{2}{|l|}{ Sex } \\
\hline Male & 11 (73.3\%) \\
\hline Female & $4(26.7 \%)$ \\
\hline No. of RT areas & 31 areas \\
\hline No. of other therapies* & $5(16.1 \%)$ areas \\
\hline
\end{tabular}

retrospectively. Four of the patients were female and 11 of them were male; the male/female ratio was 2.75/1. The median age was 63 years of age (44-76). Assessment of CKS was made based on negative human immunodeficiency virus (HIV) serology and risk factors for HIV. In addition, no patients had immunocompromised state or transplantation.

All patients received radiation and most of those were referred to palliative RT due to the pain and lymphedema in foot or the impairment of life quality. The evaluation of radiation schemes and response to RT was performed on 31 therapy areas of 15 patients. It was determined that $5(16.1 \%)$ of the therapy areas had chemotherapy, immunotherapy and/or surgical operations before RT. The general characteristics of the patients are shown in Table 1.

The follow-up was arranged as a control visit at the first month after completion of radiotherapy and then once every 3-6 months. The responses were recorded as complete response, partial response, stable disease, progression and recurrence after complete response. In order to say that complete or partial response exists, the significant decrease in pain was taken as criterion. The complete response was accepted as the improvement of the symptoms of KS lesions with residual purple pigmentation or without the pigmentation that become smooth, and the significant decrease in pain. Lesion that become smooth with regression, and the significant decrease in pain was accepted as partial response. No change in the lesion was 
Table 2. The dose and fraction schemes of radiotherapy

\begin{tabular}{ll}
$\begin{array}{l}\text { Number of treatment } \\
\text { fields }(\mathbf{n = 3 1 )}\end{array}$ & $\begin{array}{l}\text { Fractionation } \\
\text { Schemes }\end{array}$ \\
\hline 2 & $5 \times 400$ cGy \\
3 & $7 \times 400$ cGy \\
9 & $10 \times 300$ cGy \\
1 & $12 \times 300$ cGy \\
3 & $12 \times 200$ cGy \\
2 & $13 \times 200$ cGy \\
6 & $14 \times 200$ cGy \\
1 & $15 \times 200$ cGy \\
4 & $20 \times 200$ cGy
\end{tabular}

accepted as stable disease. The growth in lesion during or after therapy was accepted as progression and the repletion of the lesion at the same region after obtaining significant complete response was accepted as recurrence. ${ }^{9}$

During RT, patients were examined once a week for evaluating acute toxicities. The therapy area was assessed in the period beginning after the first week of RT and extending until one week after the end of RT. The acute toxicities included increased pain, infection, wet or dry desquamations and were recorded whether presenting or not. No grading system was used.

\section{RESULTS}

The radiotherapy: Twenty-seven (87\%) of 31 areas were treated with electron energies ranging from 3$12 \mathrm{MeV}$, one area (3.3\%) was treated with Co60, three areas $(9.7 \%)$ was treated with $6 \mathrm{MV}$ photon. The radiation fields were designed to cover the area with at least $1.5-2 \mathrm{~cm}$ margin from the gross lesion based on locations and size of the lesions. Convenient energy and dose schemes of RT was applied with daily fraction dose of 200 to 400 cGy with 5 to 20 fractions with mean 2952 (range 2000-4000) cGy according to clinical basis. Since this disease had not been seen commonly in our department, no standard dose and fraction scheme was used. On the other hand, the most frequent RT scheme was $3000 \mathrm{cGy}$ in 10 fractions. The therapy monitoring results are shown in Table 2. To ensure the dose homogeneity, boluses of different thickness $(0.5-1 \mathrm{~cm})$ were used for $22(61 \%)$ therapy areas and RT was given inside the water for two $(6.45 \%)$ therapy areas.

Tumor response and follow-up: The median follow-up time was 68.4 (13.8-120.3) months for 14 patients. Since one patient was lost to follow-up, RT response could not be assessed for one therapy area. At 6 months, complete response was obtained in 26 (86.7\%), partial response was obtained in 4 (13.3\%) of 30 therapy areas. No progression and recurrence was observed. At 12 months, complete and partial responses were seen in $28(93.3 \%)$ and $2(6.7 \%)$ areas consecutively. The radiation response of CKS was shown in Figures 1A and 1B. Of the two patients who achieved partial response, one died of infection and the other died of intercurrent disease. Thereof, the response to radiation could not be evaluated for further years. In addition, after 12 months of completion of radiotherapy, two patients developed new CKS lesions outside RT fields. They received another course of radiotherapy and one of those received systemic chemotherapy. The complete response rate did not change with the time; it was $93.3 \%$ at 5 years.

Toxicity assessment: No complication was observed in 14 therapy areas (45.2\%). Acute complication was observed in 17 therapy areas (54.8\%). Dry desquamation was observed in $2(11.8 \%)$ areas, both wet and dry desquamation was observed in $5(29.4 \%)$ areas, pain was observed in $2(11.8 \%)$ areas, and wet desquamation with infection and pain was observed in $8(47 \%)$ areas. All adverse effects developed due to the RT were controlled with support therapy. The normal foot movements were provided 2-4 weeks after RT. The therapy responses and complications of RT were shown in Table 3.

\section{DISCUSSION}

RT is an effective and safe treatment modality for KS whereas the other treatment methods such as surgery, cryotherapy, immunotherapy and chemotherapy, are of limited efficacy. It is usually preferred for patients with large number of lesions especially localized on the feet that are not appropriate for other therapies. ${ }^{4}$ 
Table 3. Response rates at 6 and 12 months and complications rates of radiotherapy

\begin{tabular}{|lll|}
\hline Therapy Response $(\mathbf{n}=\mathbf{3 0}$ areas) & At $\mathbf{6}$ months & At $\mathbf{1 2}$ months \\
\hline Complete response & $26(86.7 \%)$ & $28(93.3 \%)$ \\
Partial response & $4(13.3 \%)$ & $2(6.7 \%)$ \\
Acute Complications ( $\mathrm{n}=17$ areas) & & \\
Dry desquamation & $2(11.8 \%)$ & \\
Pain & $2(11.8 \%)$ \\
Dry and wet desquamation & $5(29.4 \%)$ & \\
Infection + wet desquamation + pain & $8(47 \%)$ & \\
\hline
\end{tabular}

RT often represents the optimal local therapy for palliation, especially lesions with pain, bleeding and lymph edema. Most of our patients were referred to our department for palliative RT due to pain and lymph edema in foot and for improvement of either their cosmetic appearance or life quality. In this small retrospective study the responses and toxicity of RT for patients with CKS in foot were evaluated.

Since the limited data was available in the literature, it is reported that the response ratios of more than $90 \%$ and complete response of $70 \%$ can be obtained in patients with different type of KS of different regions who are treated with different fraction schemes or energies of RT. ${ }^{6,10}$ Although, the varied response ratios due to single fractioned or multiple fractionated RT are shown in studies, the significant palliation can be achieved by the total dose of radiation, ranging 800-1200 cGy in one fraction to $2400-3000 \mathrm{cGy}$ in multiple fractionated scheme over 2-3 weeks $(10,11)$. Early reports suggested that $600-1200$ cGy in single fraction was effective. ${ }^{12,13}$ Cohen L. reported a study that $840 \mathrm{cGy}$ in a single fractioned local RT achieve $>86 \%$ local control rate for $\mathrm{CKS}^{14}$ and they published guidelines; suggesting RT of $800 \mathrm{cGy}$ in single fraction. ${ }^{15}$ In addition, Yildiz et al. compared a single fraction of $8 \mathrm{~Gy}$ vs $6 \mathrm{~Gy}$ in the management of KS. Majority of their patients had CKS. They reported that a single dose of $8 \mathrm{~Gy}$ is more effective in terms of complete response rates compared to $6 \mathrm{~Gy}$ (93\% vs 60\%), though overall response and progression free survival rates were similar. ${ }^{16}$ In a prospective study comparing 1600 cGy in 4 fractions over 4 days vs. an 800 cGy in single fraction, no statistical difference in overall response was shown for AIDS- associated $\mathrm{KS} .{ }^{17}$ Furthermore, in Hamilton et al. study, 37 CKS patients were received extended field RT with 800 cGy in a single fraction, $81 \%$ complete response was seen, whereas $63 \%$ of complete responders remained disease free after 3 years median follow-up time. In the literature, it is reported that a higher response rate with a longer duration of tumor control was associated with greater doses $(>2000$ cGy). ${ }^{17-19}$ One of the rare prospective randomized trial including 71 AIDS-associated KS lesions that compared $800 \mathrm{cGy}$ in one fraction and $2000 \mathrm{cGy}$ in 10 fractions or $4000 \mathrm{cGy}$ in 20 fractions, showed an a lower incidence rate of residual pigmentation and improvement in complete response rates and median time to failure with higher doses RT (19). However, it has been suggested that this data should not be interpreted as a blanket recommendation for higher dose rates. They noted that doses should be arranged to the individual patients' needs..$^{20}$ To apply an 800 cGy RT in single fraction may be appropriate for advanced AIDS associated KS' patients with painful, swollen extremities where a briefer duration of palliation is suffices and the cosmetic appearance is not important. In contrast, relatively healthy patients such as CKS' patients, who are treated to improve their cosmetic outcome, should receive relatively higher doses. ${ }^{5}$ Furthermore, it must be remembered that, higher single doses rather than small doses in fractionated schemes may cause greater late reactions in normal tissue. In our department, most of patients referred for palliation of pain and improvement of cosmesis and quality of life. Even though, no standard dose and fractionation schemes were used in our department, in contrast to single fractioned RT, smaller doses in fractionated regimens were preferred. The 

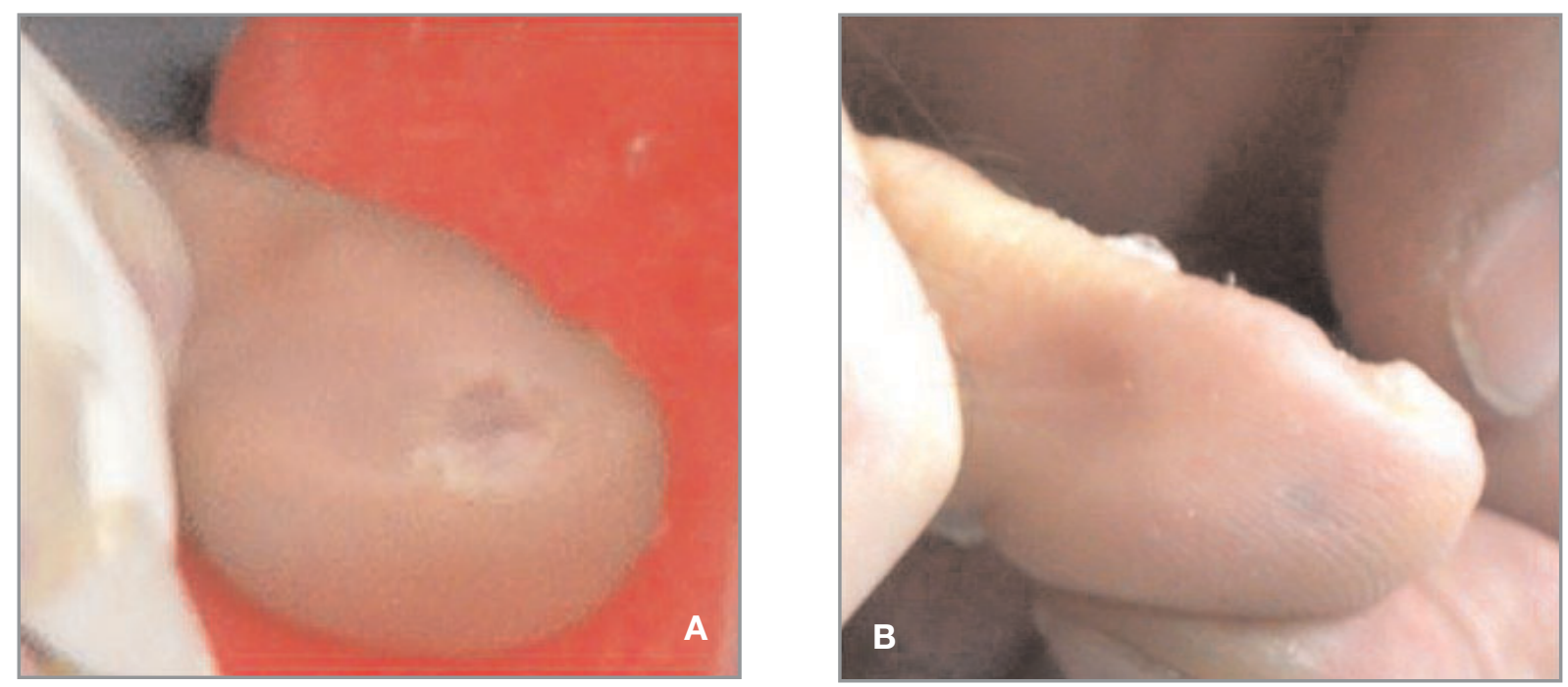

Figure 1. Images before (A) and after RT (B) of patient with $\mathrm{KS}$ at toe

most common RT schedule was 3000 cGy in 10 fractions and $2800 \mathrm{cGy}$ in 14 fractions. The mean dose of $2952 \mathrm{cGy}$ and the therapy responses were similar to those obtained in most of previously reported studies. However, the different sites of different types of KS were reported in these trials, Berson et al. evaluated 375 fields and they did not observe any difference in RT responses between all fields (>90\% response rate) and the pedal sites (96\% response rate) of AIDS related KS. ${ }^{5}$ Recently, the largest retrospective study in the literature was published. In the study 711 CKS treated with radiotherapy were evaluated. Most of the lesions (434 of 711 lesions) were located in lower limbs. A total dose of 10-40 Gy; mean dose $29.24 \mathrm{~Gy}$ (one or two weekly fractions of 5 Gy each for contact X-ray and soft X-ray RT and 2 weekly fractions of 2 Gy each for half-deep x-ray RT) were applied to patients with CKS. A mean follow-up time was 92.63 months. A complete response rate was $98.59 \%$ and a partial remission rate was $0.98 \%$ for lesions in all localizations. In the lower limbs lesions, a complete response ratio was similar $(98.15 \%)$. The response ratios did not change with time which was similar to our results; therefore the 5 year cure rate from the end of radiotherapy was $99.4 \% .^{21}$

In general, radiation is usually well tolerated with minimum toxicity. It is observed that complications with higher grades $(44 \%)$ more common in multiple fraction schemes than single fraction scheme (17\%) in assessment of 611 areas with foot localization after RT. ${ }^{5}$ Gressen et al reported a study of 36 patients treated for epidemic KS localized on the feet and received RT at a novel fractionation schedule of three fractions in a week at $3.5 \mathrm{~Gy} /$ fractionation to a total dose of $21 \mathrm{~Gy}$. Of the 35 sites assessed for acute toxicity $63 \%$ experienced discomfort related to RT. They indicated that this discomfort usually resolved with 2 weeks of completion of RT, without intervention. ${ }^{9}$ Furthermore, Cooper et al. reported that the pain and blistering in 2 of 7 patients after RT to the fe$\mathrm{et}^{22}$ and Chal et al. reported skin erythema, desquamation and pain in 5 of 7 patients after RT to the feet. The grade 3 or 4 skin toxicity occurred at a ratio of $8.3 \%$ and was treated with conservative management. ${ }^{23}$ In Caccialanza et al study, RT had been well tolerated, in 3 lesions $(0.42 \%)$ of a same patient, localized at the ankle, an acute radiodermatitits occurred after traumatic action of a shoe while walking, shortly after the end of RT. However, all three lesions healed with medical treatments. ${ }^{21}$ In our study, the ratio of acute complications was $54.8 \%$ and it was seen that a complete improvement was occurred with convenient support therapy and normal foot movements were provided within 2-3 weeks after completion of RT, which were similar to the literature. There were no severe acute reactions to stop the treatment.

In conclusion, the RT is an optimal local treatment for palliation of foot KS. It elicits perfect response ratios with the responses seen in KS of other skin regions. The patients with KS in foot should be informed that pain or foot discomfort will be increased 
during the therapy and it should be said that this situation will be improved completely with supportive therapy. Because the response to radiation is usually frustrating and the foot complaint may temporarily increase due to the acute edema. It should be noted that, the sub-types of the KS, the regions of the disease and RT schemes were shown differences between the studies; moreover the data about the evaluation of response to RT for CKS of the foot was limited. We reported our experience for this subgroup that is rarely seen, although the prospective studies with more cases are warranted to obtain the efficacy and toxicity of RT in terms of determines the standard dose and fractionation schedule.

\section{REFERENCES}

1. Kaposi M. Idiopathisches multiples pigmentsarcom der haut. Arch Dermatol Syphilol 4: 265, 1892.

2. Weissmann A, Linn S, Weltfriend S, Friedman-Birnbaum R. Epidemiological study of classic Kaposi's sarcoma: a retrospective review of 125 cases from Northern Israel. J Eur Acad Dermatol Venereol 14: 91-95, 2000.

3. Di Lorenzo G. Update on classic Kaposi sarcoma therapy: new look at an old disease. Crit Rev Oncol Hematol 68: 242-249, 2008.

4. Hauerstock D, Gerstein W, Vuong T. Results of radiation therapy for treatment of classic Kaposi sarcoma. J Cutan Med Surg 13: 18-21, 2009.

5. Berson AM, Quivey JM, Harris JW, Wara WM. Radiation therapy for AIDS-related Kaposi's sarcoma. Int J Radiat Oncol Biol Phys 19: 569-575, 1990.

6. Cooper JS, Steinfeld AD, Lerch IA. Intentions and outcomes in the radiotherapeutic management of epidemic Kaposi's sarcoma. Int $J$ Radiat Oncol Biol Phys 20: 419-422, 1991

7. Langtry JA, Bottomley DM, Philips RH, Staughton RC. The infra-red coagulator in the treatment of AIDS-related Kaposi's sarcoma and a comparison with radiotherapy. Clin Exp Dermatol 19:23-25, 1994.

8. Safai B. AIDS-related Kaposi's sarcoma: therapy options for today and tomorrow. Oncology 10: 1-38, 1996.

9. Gressen EL, Rosenstock JG, Xie Y, Corn BW. Palliative Treatment of Epidemic Kaposi Sarcoma of the Feet. Am J Clin Oncol 22: 286-290, 1999.

10. Stein ME, Lakier R, Spencer D, et al. Radiation therapy for non-AIDS associated (classic and endemic African) and epidemic Kaposi's sarcoma. Int J Radiat Oncol Biol Phys 28: 613-619, 1994.

11. Chang LF, Reddy S, Shidnia H. Comparison of radiation therapy of classic and epidemic Kaposi's sarcoma. Am J Clin Oncol 15: 200-206, 1992.
12. Lo TC, Salzman FA, Smedal MI, Wright KA. Radiotherapy for Kaposi's sarcoma. Cancer 45: 684-687, 1980.

13. Holecek MJ, Harwood A. Radiotherapy of Kaposi's sarcoma. Cancer 41: 1733-1738, 1978.

14. Cohen L. Dose time and volume parameters in radiation therapy of kaposi's sarcoma. Br J Radiol 35: 485489, 1962

15. Cohen L, Palmer PE, Nickson JJ. Treatment of Kaposi's sarcoma by radiation. Acta Unio Int Contra Cancrum 18: 502-509, 1962.

16. Yildiz F, Genc M, Akyurek M, et al. Radiotherapy in the management of Kaposi's sarcoma: Comparison of 8 Gy versus 6 Gy. J Natl Med Assoc 98: 1136-1139, 2006.

17. Harrison M, Harrington KJ, Tomlinson DR, Stewart JS. Response and cosmetic outcome of two fractionation regimens for AIDS-related Kaposi's sarcoma. Radiother Oncol 46: 23-28, 1998.

18. Cooper JS, Steinfeld AD, Lerch IA. The prognostic significance of residual pigmentation following radiotherapy of epidemic Kaposi's sarcoma. J Clin Oncol 7: 619-621, 1989.

19. Stelzer KJ, Griffin TW. A randomized prospective trial of radiation therapy for AIDS-associated Kaposi's sarcoma. Int J Radiat Oncol Biol Phys 27: 1057-1061, 1993.

20. Donahue BR, Cooper JS. Malignant neoplasms associated with the acquired immunodeficiency syndrome. In: Principle and Practice of Radiation Oncology. Perez CA, Brady LW, Halperin EC, SchmidtUllrich RK (eds). Philadelphia, Lippincott Williams and Wilkins, 5th ed. 2008: 702-716.

21. Caccialanza M, Marca S, Piccinno R, Eulisse G. Radiotherapy of classic and human immunodeficiency virus-related Kaposi's sarcoma: results in 1482 lesions. JEADV 22: 297-302, 2008.

22. Cooper JS, Fried PR. Defining the role of radiation therapy in the management of epidemic Kaposi's sarcoma. Int J Radiat Oncol Biol Phys 13: 35-39, 1987.

23. Chak LY, Gill PS, Levine AM, et al. Radiation therapy for acquired immunodeficiency syndrome-related Kaposi's sarcoma. J Clin Oncol 6: 863-867, 1988.

\section{Correspondence}

Dr. O. Petek ERPOLAT

Konutkent 2 A-8 Blok No:62

Cayyolu / Ankara-TURKEY

e-mail: petektater@yahoo.com 